\title{
Analysis on the Net Loan of Beijing's College Students \\ Yuan-Yuan WANG
}

North China Electric Power University School of Economics and Management 1123362210@qq.com

Key words: Beijing, College students, Net loan.

\begin{abstract}
Net loan has become a trend among college students. Net loan is helpful to broaden the financing channels and ease the shortage of funds for college students. However, net loan also brings a series of puzzles and distress at the same time. The article is based on the survey of Beijing's college students and compares domestic date which obtained from the survey to analyze Beijing's college students' demands and use of net loan and their repayment situation, hoping to offer suggestions on making proper use of net loan for college students.
\end{abstract}

\section{Introduction}

Since credit cards for students were stopped by the CBRC, net loan platforms have strongly intervened in college students' market. As the special group of transition from school to society, college students' sources of funds are single while their consuming demands are relatively exuberant, making them possibly faced shortage of funds. When faced with shortage of funds, part of college students would choose net loan platforms which offer low thresholds and convenient service. With loan tragedy events occurring frequently in recent times, we can't pay too much attention to the security of net loan. We made investigations of Beijing's college students' loan situation, comparing it to the national college students' loan situation in order to offer suggestions on making careful use of net loan, hoping to guide college students to consume rationally and treat net loan correctly.

\section{Analysis on the College Students' Demands of Net Loan and Attitudes towards It}

\section{In the Group of College Students, the Shortage of Funds is Widespread. There's a Certain Demand of Net Loan among Them.}

The shortage of funds is prevalent among college students. As is shown in Table One, approximately $22 \%$ of students always have a shortage of funds, $56 \%$ have occasional shortage and only $22 \%$ never have funding shortage.

The relatively higher data of Beijing reflects that the price level in Beijing is higher than domestic average level. As the capital city of China, Beijing is rich in material life, bringing more temptation to college students and increasing students' material demands. These are part of reasons why the proportion of Beijing's college students of using net loan is higher than domestic average level.

Table One

\begin{tabular}{|l|l|l|}
\hline The shortage of funds of college students & Domestic data & Beijing's data \\
\hline Never & $22 \%$ & $24 \%$ \\
\hline Occasionally & $56 \%$ & $62 \%$ \\
\hline Always & $22 \%$ & $14 \%$ \\
\hline
\end{tabular}

Similarly, in the survey in Beijing, we found that $14 \%$ of college students are always short of funds with remaining living expenses less than zero, $62 \%$ of students occasionally lack funds, only $24 \%$ of them are in good financial conditions. Beijing's data is roughly equal to domestic data, revealing that it's a common phenomenon that college students are occasionally lack of funds. At 
the same time, we see that $77.45 \%$ of Beijing's college students are likely to turn to net loan for financial support when they have strong desires to purchase something that they can't afford in a time. This just reflects that there's a certain demand of net loan among college students.

\section{College Students Rarely Use Net Loan in Fact, the Proportion of Students Using Net Loan is Higher Than Domestic Average Level.}

As is shown in Table Two, college students of using net loan make up a small part of all students. Additionally, the proportion of students of using net loan platforms among freshmen, sophomore students and junior students is $12.02 \%, 24.82 \%$ and $39.57 \%$. All the data here is higher than domestic data. The proportion of college students of using net loan platforms is raising with the growth of grades, which reveals a new problem that the demands of net loan is increasing and the possibility of students' using net loan is also increasing with the extension of school time.

Table Two

\begin{tabular}{|l|l|l|}
\hline Proportion of college students of using net loan & Domestic data & Beijing's data \\
\hline College students from diverse grades & $14 \%$ & $23.5 \%$ \\
\hline Freshmen & $4.32 \%$ & $12.02 \%$ \\
\hline Sophomore students & $12.5 \%$ & $17.6 \%$ \\
\hline Junior students & $24.82 \%$ & $39.56 \%$ \\
\hline
\end{tabular}

\section{Compared to Other Domestic College Students, Beijing's College Students' Attitude towards Net Loan is more Neutral.}

Domestic data reflects that more than $75 \%$ of college students assume that net loan brings more harm than good. Most of them insist in believing that students produce advanced consuming behavior partly because of the platforms' financial support. The phenomenon that parts of net loan platforms are not standardized and information provided by platforms is misleading increases students' mistrust.

Beijing's data shows us that more than half of college students have a neutral attitude towards net loan, indicating that if the case of insufficient funds occurs again, they would probably turn to net loan for financial help. Compared to domestic college students' overall attitude, Beijing's college students tend to take a more neutral attitude.

\section{Analysis on the Use of Net Loan of Beijing's College Students}

\section{College Students of Using Net Loan Mainly Use the Credit Services Provided by Traditional Electronic Business Platforms}

Campus net loan is generally divided into three kinds. The first kind is credit services provided by electronic business platforms, such as Jing dong IOUs and Ants check later. The financial model of consuming via electronic platforms is based on big data, making credit evaluation based on historical transaction data, thus crediting for college students. The second is stage shopping platforms aiming at college students, such as IOUs by stages. The third is P2P net loan platforms, such as Elite Loan.

As is shown in Table Three, Domestic data reflects that $64 \%$ of students who loan use Ant check later and other electronic business platforms, $15 \%$ choose IOUs by stages and other stage platforms , $19 \%$ select Elite loan and other P2P net loan platforms. In addition, only $2 \%$ of them loan in other ways.

Beijing's data shows that among the college students who use net loan, 91.09\% have used credit services provided by electronic business platforms. , $7.25 \%$ have used IOUs by stages and 4.68\% have used Elite loan. Compared with domestic data, the proportion of Beijing's students of using other net loan platforms except electronic business platforms is surprisingly low, indicating the caution of selecting the net loan mode among Beijing's college students in some ways. Influenced 
by a series of net loan tragedy events, majorities don't believe in small net loan platforms any more. They prefer to trust electronic business platforms with normal operating modes and large scales rather than believe in Third Party net loan platforms whose scales are small. The phenomenon that college students who loan via the Internet mostly select the credit services provided by electronic business platforms is closely related with their consumption habits. College students are accustomed to shopping on diverse large shopping sites. What's more, the publicity of these electronic business platforms greatly improves the visibility of Ant check later and Jing dong IOUs among college students.

Table Three

\begin{tabular}{|l|l|l|}
\hline $\begin{array}{l}\text { Selection of net loan platforms among } \\
\text { college students }\end{array}$ & Domestic data & Beijing's data \\
\hline $\begin{array}{l}\text { Ant check later and other electronic } \\
\text { platforms }\end{array}$ & $64 \%$ & $91.09 \%$ \\
\hline $\begin{array}{l}\text { IOUs by stage and other stage shopping } \\
\text { platforms }\end{array}$ & $15 \%$ & $7.25 \%$ \\
\hline Elite loan and other P2P net loan platforms & $19 \%$ & $4.68 \%$ \\
\hline Other net loan platforms & $2 \%$ & $0.85 \%$ \\
\hline
\end{tabular}

\section{College Students Use Net Loan Mainly to Purchase Electronic Equipment And Other High-End Consumer Goods.}

According to Table Four, money borrowed from net loan platforms, $41.89 \%$ of college students used to buy electronic equipment, $26.29 \%$ used to purchase cosmetics and clothing and $12.16 \%$ for investment and education. From Beijing's data, 43.84\% of college students used money borrowed from platforms to purchase electronic equipment, $40 \%$ used it to purchase cosmetics and clothing, only $28.51 \%$ for education and investment.

Table Four

\begin{tabular}{|l|l|l|}
\hline Purposes of net loan among college students & Domestic data & Beijing's data \\
\hline Electronic equipment & $41.89 \%$ & $43.83 \%$ \\
\hline Cosmetic and clothing & $26.29 \%$ & $40 \%$ \\
\hline Education and investment & $12.16 \%$ & $28.51 \%$ \\
\hline
\end{tabular}

These data displays that money borrowed from net loan platforms is mainly used to purchase electronic equipment, cosmetics and clothing. The ratio of loaning for education and investment is low. Electronic equipment and other high-end consumer goods are hard for college students to afford in a short time. Therefore, they tend to choose installment purchase via platforms. Although food and other consumer goods are a necessity, their prices are within the affordable range. These data reflects that college students use net loan mainly for enjoyment consumption, less for development expenditure.

\section{Analysis on Repayment Situation of Beijing's College Students}

\section{College Students Mostly Repay the Loan by Saving Living Expenses. The Proportion of Beijing's College Students Who Repay the Loan by Doing Part-Time Jobs is relatively Low.}

In the domestic survey of repayment situation, $78.57 \%$ of students repay the loan by saving living expenses, $50 \%$ of students repay the loan by doing part-time jobs.

On the way of payment, $63.53 \%$ of students Beijing's college students repay the loan by saving living expenses,28.09\% repay it by the way of doing part-time jobs, $14.47 \%$ repay by looking for parents' help and $11.49 \%$ use the scholarship won by their hard study to repay the loan. Repayment methods of Beijing's college students are more diverse, but the proportion of choosing part-time 
jobs is lower than domestic level.

\section{College Students' Repaying Ability is lower Than Expected. The Pressure of Repayment among Beijing's College Students is relatively Small.}

According to domestic data, the phenomenon of overdue return occurs among college students who loan. To make things worse, part of college students overlap via net loan platforms and are trapped in the dilemma of overdue return. Their sources of funds for repaying the loan are single. In fact, for their own loan behavior, 54.04\% of the students didn't tell their parents about the matter, which worsens the repayment situation.

Deferred repayment of Beijing's college students accounts for $21.28 \%$, in which delayed repayment due to lack of money only accounts for $6.8 \% .54 .89 \%$ of students of using net loan said that the repayment pressure is not great. On the whole, the phenomenon that the repayment situation of Beijing's college students is better than domestic average level has a certain relationship with the existence of some Beijing's college students who have better economic conditions and have places of origin in Beijing. At the same time, majorities match loan limit with repayment ability when they loan, accounting for their lower

\section{Suggestions on the use of net loan for college students}

\section{Consume Rationally, Avoid Following the Trend Blindly and Avoid Excessive Consumption.}

In the survey, we found that few college students have the habit of keeping a diary to record payments. As the consequence, it's difficult to estimate the spending and the remaining funds in time. With the presence of the collective net loan in the same dormitory, we suggest that students should avoid following other students to make lead consumption. College students are suggested to record daily balance of payments in time, trying to make ends meet. If there's particular goods to buy, students are supposed to save funds in advance instead of loaning blindly.

\section{Avoid being too Dependent on Electronic Business Platform. Be Aware of the Consequences of Delayed Repayment.}

This is a special suggestion for Beijing's college students. Too many students overly trust credit services provided by Jing dong IOUs, Ant check later and other electronic business platforms. Worse still, most of students are not aware of the consequences of delayed repayment. After using these credit services, personal loan information may appear in the central bank's personal credit report. Delayed repayment would exert a bad influence to personal credit scores and future bank loan procedures. Therefore, selecting electronic business platforms to loan requires carefulness as well.

\section{Standard Net Loan Platforms' Operating Modes, Appropriately Raise Lending Threshold and Strict the Credit Process.}

There's vicious competition between net loan platforms. With low lending threshold, simple procedures and non-standard credit process, users can loan easily.Net loan platforms' providing a large amount of loans to college students without a strict evaluation of the college students' repayment ability is the violation of property security of college students in some ways. Therefore, it's essential for the government to standard net loan platforms' operating modes, raise lending thresholds and strict the credit process.

\section{Summary}

From the data we have investigated and sort out, we can come to the preliminary conclusion that most of college students take a cautious attitude towards net loan. But there are also many problems existing in the use of net loan. For example, college students use net loan mainly to satisfy material demands. Another is that college students' repaying ability is lower than expected. These problems above reflect that the college students' consumption habits require improvement, also reminding us 
that the credit process needs to be standardized and lending thresholds require to be raised.We hope that the conclusions and suggestions can provide college students with some reference on the net loan.

\section{References}

[1] Berger, Sven C; Gleisner, Fabian. Emergence of Financial Intermediaries in Electronic Markets: The Case of Online P2P Lending [J].Business Research, 2015:39-65. 